\title{
NADGIŚNIENIE TETTIGZE
}

Redaktor działu: prof. dr hab. n. med. Krzysztof Narkiewicz

\section{Komentarz}

\section{The commentary}

\section{prof. dr hab. n. med. Krzysztof Narkiewicz}

Katedra Nadciśnienia Tętniczego i Diabetologii Gdańskiego Uniwersytetu Medycznego

Żyjemy w świecie medycyny opartej na dowodach naukowych (EBV, evidence-based medicine). Ogromny postęp w terapii chorób układu sercowo-naczyniowego dokonał się w dużej mierze właśnie dzięki randomizowanym badaniom klinicznym. Najważniejsze z nich (tzw. landmark trials) zrewolucjonizowały zarówno zalecenia, jak i codzienną praktykę kliniczną. Do takich momentów przełomowych w historii kardiologii z pewnością należy opublikowanie wyników badania ASCOT (Anglo-Scandinavian Cardiac Outcomes Trial), w którym udokumentowano: 1) przewagę nowoczesnej terapii hipotensyjnej (amlodypina/peryndopryl $v$. beta-adrenolityk/diuretyk) w prewencji zdarzeń sercowo-naczyniowych; 2) koniecznośćleczenia statynami większości chorych z nadciśnieniem tętniczym; 3) korzyści wynikające $\mathrm{z}$ jednoczasowego stosowania nowoczesnego złożonego leczenia hipotensyjnego i statyn. Należy w tym miejscu zauważyć, że ta- kich dowodów nie mamy dla połączenia sartanów z antagonistami wapnia.

Potwierdzenie przewagi danego sposobu terapii w randomizowanym badaniu klinicznym, mimo przekonujących hipotez i wcześniejszych danych dotyczących mniejszych grup chorych, nie jest rzeczą oczywistą. Większość badań klinicznych przynosi wyniki "neutralne”, a nierzadko są to badania "negatywne" odsyłające dany sposób terapii do historii medycyny. Natomiast ASCOT było przykładem badania, którego jednoznacznych wyników nigdy nie kwestionowano i bardzo szybko wpłynęły na kształt zaleceń dotyczących leczenia chorób układu sercowo-naczyniowego.

Jednym z potencjalnych zarzutów wobec randomizowanych badań klinicznych jest ich stosunkowo krótki okres trwania (zwykle 3-5 lat) w porównaniu z kontynuowaniem leczenia w praktyce klinicznej przez okres znacznie dłuższy, obejmujący nieraz kilka- dziesiąt lat. Należy jednak pamiętać, że udokumentowane utrzymywania się korzystnych efektów pierwotnie zastosowanej terapii w okresie po zakończeniu badania jest niezwykle trudne. Chorzy w tym okresie nie pozostają już pod stałą opieką ośrodków badaczy, a ich leczenie jest zmieniane zgodnie z nowymi standardami. Po zakończeniu okresu randomizacji obie grupy chorych są leczone de facto w ten sam sposób, a w pełni wiarygodnymi pozostają jedynie dane dotyczące śmiertelności.

Badanie ASCOT-Legacy, omówione szczegółowo przez Panią doktor Szyndler, jest pierwszą tak długą obserwacją chorych, w której udokumentowano wieloletnią skuteczność nowoczesnego leczenia hipotensyjnego. Wybór wyjściowego sposobu terapii hipotensyjnej wpływał na ryzyko sercowo-naczyniowe oceniane 10 lat po zakończeniu randomizowanej fazy badania. W szczególności leczenie amlodypiną/peryndoprylem wiązało się z niższym ryzykiem zgonu 
z powodu udaru mózgu, który jest najbardziej dewastującym powikłaniem nadciśnienia tętniczego. Warto podkreślić, że chorzy włączeni do badania ASCOT bardzo dobrze odzwierciedlają rzeczywistą populację pacjentów z nadciśnieniem tętniczym (także w Polsce) pod względem poziomu ryzyka sercowo-naczyniowego.

Autorzy badania ASCOT-Legacy podkreślają, że za utrzymywanie się korzystnego, niezależnego od obniżenia ciśnienia tętniczego, efektu terapii amlodypina/peryndoprylem może być odpowie- dzialnych wiele mechanizmów, między innymi lepsza stabilizacja blaszki miażdżycowej, korzystniejsze efekty metaboliczne, większe obniżenie centralnego ciśnienia tętniczego oraz większa redukcja zmienności ciśnienia tętniczego. Należy podkreślić, że trwają dalsze analizy (m.in. badania genetyczne), które, być może, ułatwią w przyszłości - zgodnie z koncepcją medycyny precyzyjnej dalszą indywidualizację leczenia przeciwnadniśnieniowego.

Autorzy najnowszych zaleceń europejskich, przedstawionych po raz pierwszy w czerwcu 2018 roku, bardzo mocno preferują połączenie leków hamujących układ renina-angiotensyna i antagonistów wapnia, rekomendując (pierwsza klasa rekomendacji) stosowanie leków skojarzonych. Wyniki badania ASCOT-Legacy, opublikowane kilka miesięcy po przedstawieniu tych zaleceń wzmacniają, bez wątpienia, pozycję preparatu złożonego amlodypina/peryndopryl jako optymalnego sposobu rozpoczynania i kontunuowania leczenia chorych z nadciśnieniem tętniczym. 